$\mathrm{Oz}$

Volume 37

Article 6

$1-1-2015$

\title{
Local Code: Real Estates
}

Nicholas de Monchaux

Follow this and additional works at: https://newprairiepress.org/oz

Part of the Architecture Commons

(c) (1) $(9$

This work is licensed under a Creative Commons Attribution-Noncommercial-No Derivative Works 4.0 License.

\section{Recommended Citation}

de Monchaux, Nicholas (2015) "Local Code: Real Estates," Oz: Vol. 37. https://doi.org/10.4148/

2378-5853.1544

This Article is brought to you for free and open access by New Prairie Press. It has been accepted for inclusion in Oz by an authorized administrator of New Prairie Press. For more information, please contact cads@k-state.edu. 


\author{
Nicholas de Monchaux
}

Popular images of entropy-a breaking glass, the lowering heap of compost, even our own descent into dust, provide a familiar, but subtly inaccurate thermodynamic picture. Viewed through an informational as well as physical lens, entropy is not a consistent movement towards flatness and uniformity, but something else as well. A true random number generator, for example, (an electronic service purchased by lotteries and statisticians), only manages to avoid the inevitable, subtle informational patterning of manmade algorithms by taking the form of a constant, radio-telescopic reading of the cosmic background radiation, the dispersed entropy of our universe's founding instant. This stochastic distribution is precisely not an expression of uniformity, but rather of unpredictable difference and unavoidable distinction

Particularly in a world ever more subject to digital sampling, measurement, and positioning, one of the most essential opportunities might be not (as is currently the fashion) to seek virtuosic systems of order, or even coordination but rather, to better examine, and instrumentalize disorder, disorganization, and the difference between the world as we structure it conceptually, and the world as it actually is. Local Code : Real Estates, an attempt at such a design practice, is a project that seeks to identify and transform identifies legally and socially abandoned urban and marginal conditions through emergent, digitally-mediated methods into a social, and ecological resource. It takes as its starting point an instrumental and unfinished project by Gordon Matta Clark: Fake Estates:Reality Properties.

Between 1971 and 1974, it took Matta-Clark many hours of sifting through newsprint catalogs to locate the fifteen vacant and moribund sites-fragments of New York real estate-that form the work Fake Estates:Reality Properties. Photographs, maps, and property deeds for the sites, collected by MattaClark, were assembled by his widow, Jane Crawford, into exhibitable artworks in 1992, at the invitation of the curator, Corrine Disenrens, of Matta-Clark's major retrospective at the IVAM in Valencia, Spain. Today, using a Geographic Information System, or GIS, the same search can be accomplished in minutes, and locates many thousands of marginal, city-owned vacant lots throughout the five boroughs of New York. When Matta-Clark's Fake Estates were first presented together, the mere fact of their documentation, was cause for attention. Today, however, Fake Estates maybe essential in considering how we might respond to a revolution that has occurred since that time: the almost uniform presence of digital information in our encounters with, and designs for, cities.

\section{Real Estates}

This is especially true since New York, of course, is not unique. Analysis of other North American cities shows a similar pattern of urban vacancy: thousands of remnant parcels and hundreds of acres of fallow public land. As one example, a case study of San Francisco reveals over 1,500 city-owned remnant parcels. Seen separately and individually, these are litter-filled, residual spaces, condensing around highways and industrial sites. When accumulated and considered together, however, the sites can be seen as a unified, if unsettling, figure. This is especially true when we deploy digital techniques to study more commonlyconsidered indicators of neglect and decay. Against this background, these sites outline an uneasy penumbra of urban freeways, as well as the outlines of entire neighborhoodsHunter's Point, Bayview, the Outer Mission, that are, in the city's usual debates, precisely "off the map."

Forming a distributed surface that rivals Golden Gate Park, a targeted, land-banking renovation of these sites has enormous potential to relieve the very same problems the presence of the sites seems to track. For each of the 1,625 Local Code proposals for San Francisco shown here, a GIS model of water flow, sun, and wind movement parametrically govern the dispersal on each site of a range of hardscape and softscape, mediating air quality, drainage and energy loads, and enhancing both site and city. Further speculations imagine that the same digital media used to isolate and identify each site could serve further as a test-bed for community engagement and further design, as well as digitally-based fabrication.

This proposal draws from established, and important precedents in neighborhood greening at the local scale-such as in Baltimore, Chicago, and Los Angeles. These efforts, however, have been justified on substantially social and political grounds. Through locally optimizing the energy performance and water storage and remediation potential of such sites, however, Local Code sustains a policy argument at the level of the entire urban field. As but one example, a $\$ 1.5$ billion bond measure was recently approved last year to upgrade the capacity of San Francisco's combined sewer system to better manage peak flow. Using established engineering metrics and the parametrically-derived hydrology of each of the thousand-plus design proposals shown here, a large part of this investment could be replaced by surface spending, introducing open space and resources into the city's most park-poor neighborhoods.

But here, too, we might particularly remember several important caveats to such an elaborate system-driven process; many are encountered in the incandescent, unfinished life of Matta-Clark himself.

\section{The Ongoing Fallacy}

Central to Matta-Clark's view of urban design was the experience of his father, Robert Matta, who worked for two years in the "scientific" studio 

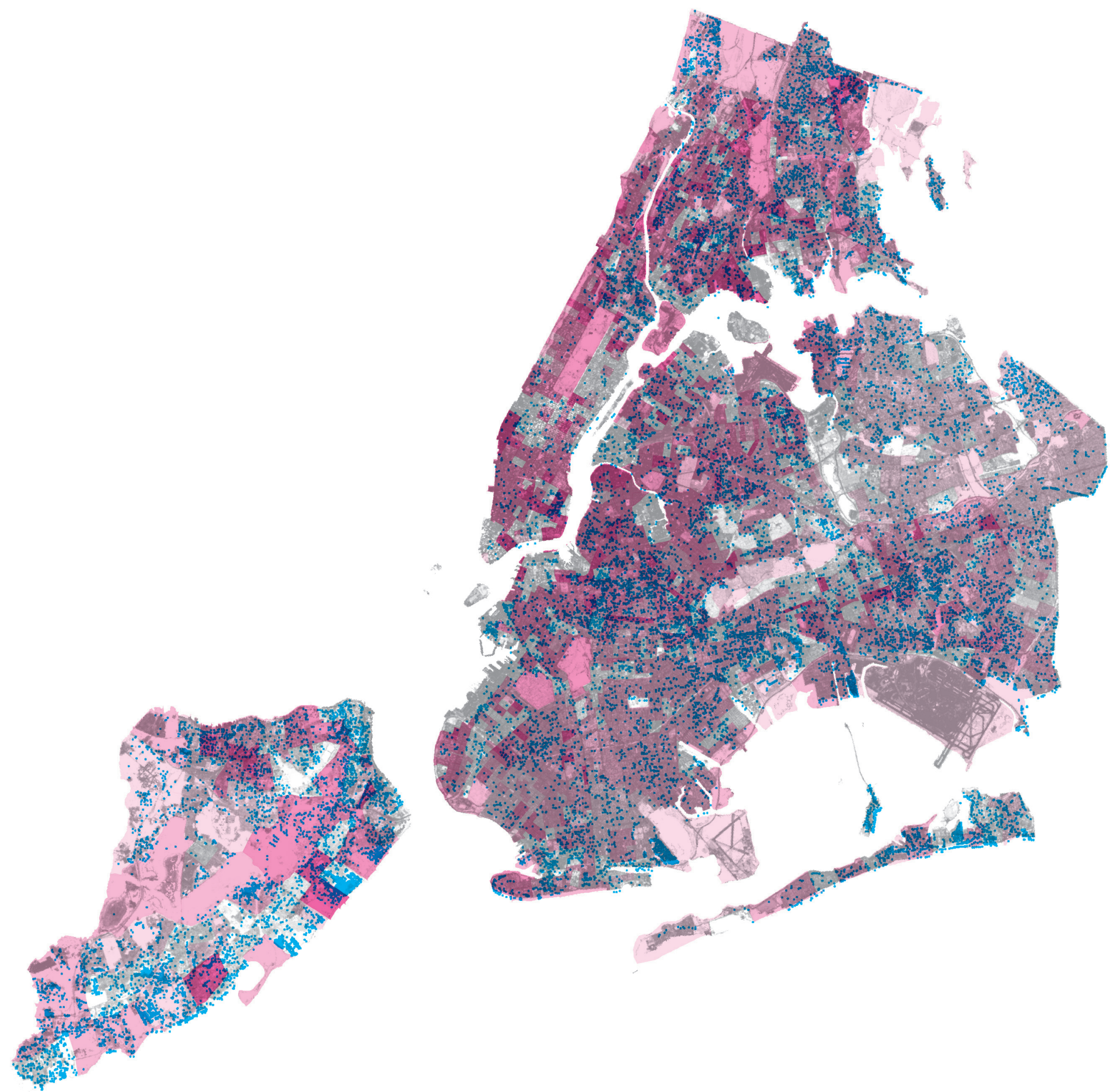

A contemporary GIS Analysis of New York City showing the location of Gordon Matta-Clark's Fake Estates, (in red) as well as a GIS discovery of over 4,000 similar sites, totaling over 700 acres. 
of Corbusier, drafting much of the Ville Radieuse before rejecting the master's work as suitable only for a (nonexistent) "creature that lived in perfect harmony with the society and his work." Matta-Clark traced his own interest in adaptive reuse to the observation that "the availability of empty and neglected structures [is] a prime textual reminder of the ongoing fallacy of renewal through modernization."

Rosalind Krauss begins her 1996 essay-collaboration with Yves-Alain Bois, “A User's Guide to Entropy," with a thermodynamic consideration that parallels the epigrammatic physics with which own discussion began. In particular, Krauss cites Robert Callois' description of "hot and cold water mixing together to settle into a uniformly tepid blandness," as well as Robert Smithson's fluid image of a boy running circles in a sandbox, mixing black and white grains in an ever-greyer "movement towards uniformity." In the subsequent text, several sections (contributed by Bois) consider the work of Gordon Matta-Clark as exemplary of "entropic" practice. Ordering MattaClark's works' collective disorder in successive scales, Bois considers first the artist's experiments in molding, layering and burning physical objects, (such as the scorched, goldleafed Polaroid prints of "PhotoFry") moving on to the cutting and dis-membering of buildings, and concluding with an extended consideration of Fake Estates. Bois emphasizes throughout the "sovereign contempt in Matta-Clark's attitude toward architects"; the artist's violent rejection not only of high modernism, but of the formalist, autonomous discourse that, during Matta-Clark's own architectural education at Cornell from 1965-69, proposed its replacement.

Matta-Clark's rejection was, of course, never so vivid as when he shot out the windows of Peter Eisenman's Institute for Architecture and Urban Studies with an air rifle. The violence of the act, at least for Matta-Clark himself, deliberately recalled the abandoned, shardshrouded interiors of New York's great modernist housing projects, which by the 1970s were far more abandoned and blighted than the ostensibly obsolete urban fabric they replaced. Matta-Clark had originally been asked to perform a series of cuts and spatial operations on the Institute's conference room, as part of a group show, "Idea as Model," that also included Richard Meier, Charles Gwathmey, and Michael Graves. Early in the dark morning of the exhibit's installation, Matta-Clark arrived instead with a series of photographs of these vandalized apartment blocks, and an air Rifle borrowed from the artist Dennis Oppenheim. After requesting permission to shoot out a few, already broken windows in the Institute's façade, he proceeded to destroy every one.

If the Institute's "white" formalism was a child of modernism, then it is also an, influential ancestor of contemporary data-driven practice, whose formal autonomy-as well as bleached complexion-bear witness to the bloodline. Standing between these generations is the 1990's particular formalist turn, "Deconstruction," whose attempts to appropriate the work of MattaClark are held in particular derision. Bois adopts Matta-Clark's voice for the purpose; "What I do, you could never achieve, since that presupposes accepting ephemerality... architecture has only one destiny, and that is, sooner or later, to go down the chute..."

\section{Network Enclosures}

Yet if Matta-Clark's creative destruction was anathema to its mid90s Deconstructivist appropriation, we can find some, tantalizing evidence of the artist's renewed interest in more alternative modes of constructive architectural practice at the time of his death in 1978. One of Matta-Clark's last, unfinished works was the physical construction of a community center on an unused site on Manhattan's Lower East Side, for which he had received a Guggenheim grant at the time of his death in 1978. Matta-Clark described the audience for his own community center proposal as precisely "a network of community groups and individuals engaged in open space and rehab projects, sweat equity, community gardens, playlots, cultural events, alternative living structures, etc," adding that the proposal "has brought these groups together."

Matta-Clark's use of the word "network" is notable. At the same time, as he engaged his own design work more and more with the real and social fabric of cities, MattaClark also became intrigued by, what was at the time, the stateof-the-art in digital practice. For a nascent project, on what Matta-Clark termed "network enclosures," the artist wrote shortly before his death to both MIT and UCLA requesting use of digital architectural, mapping, and visualization software, declaring the use of computers "a part of my search to chart and reoccupy space”. Today, much of contemporary algorithmic design borrows a network language, particularly the language of complex, non-hierarchical natural systems. We should remember that one of the earliest critics to connect such biological theories of emergence with urban design was, like MattaClark, a student of Manhattan.

\section{Death and Life}

When, in the last chapter of her 1961 opus The Death and Life of Great American Cities, "The Kind of Problem a City Is," urban activist Jane Jacobs sought to articulate a metaphor for urban planning distinct from the "collection of file drawers" she abhorred, she turned to the same 1958 annual report of the Rockefeller Foundation Annual Report in which her own two-thousand dollar grant for Death and Life was published. In an essay marking his retirement from twenty-five years leading Rockefeller's work in the "natural" sciences Dr. Warren Weaver, had specifically identified new thinking in the natural sciences describing “organized complexity." Quoting from Weaver's essay, Jacobs makes a case for the special affinity between urban landscapes and biological systems. Invoking the example of a single urban park, she submits that any attempt to isolate the variables, however many, leading to the success or failure of an urban enterprise is inherently dubious; such variables are too numerous and interconnected.

The Rockefeller Foundation's subsequent funding played a catalytic role in today's interdisciplinary discussions of emergent form, and in particular the adoption of a biologically-inflected, "morphogenetic" language in formalist, "parametric" proposals. The apparently coded and constructed quality of biological systems, however, may turn out to be just that Recent work in evolutionary biology has underlined a new understanding, that the relationship between genetic content and resulting form, far from occurring measurably, are interconnected, numerous, and, as Jane Jacobs said of urban variables, "as slippery as an eel." In such a context we might reflect, then, on Adrian Forty's observation that the consistent application of natural, and particularly biological, language to architecture (as particularly evidenced in the formalist discourses noted above) has served historically a persistent barrier to considering the manifold natural systems to which a building is actually connected. Most problematically, such metaphors 


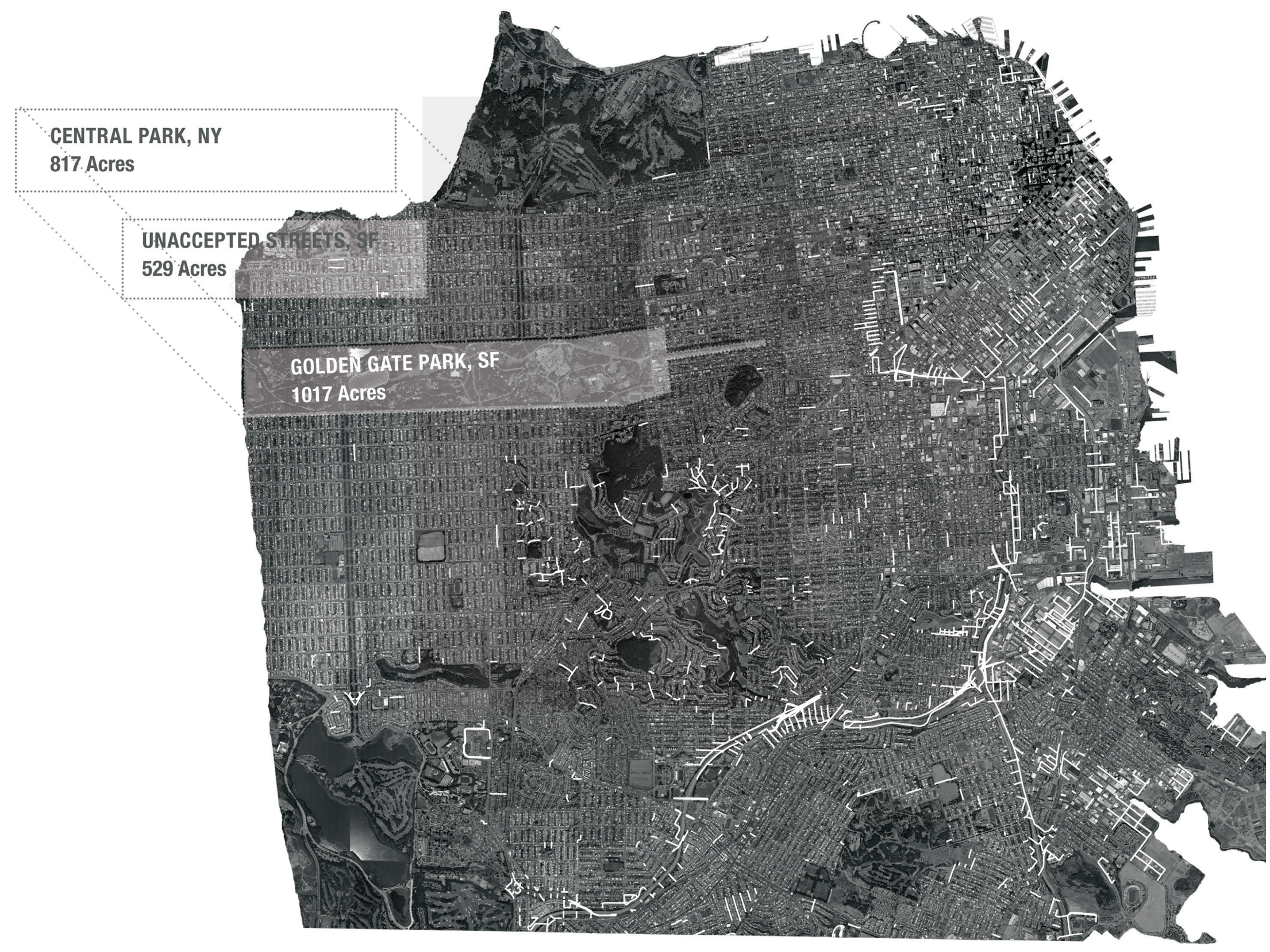

The scale and distribution of San Francisco's Unaccepted Streets - the vacant, city-owned parcels considered by Local Code : Real Estates. 


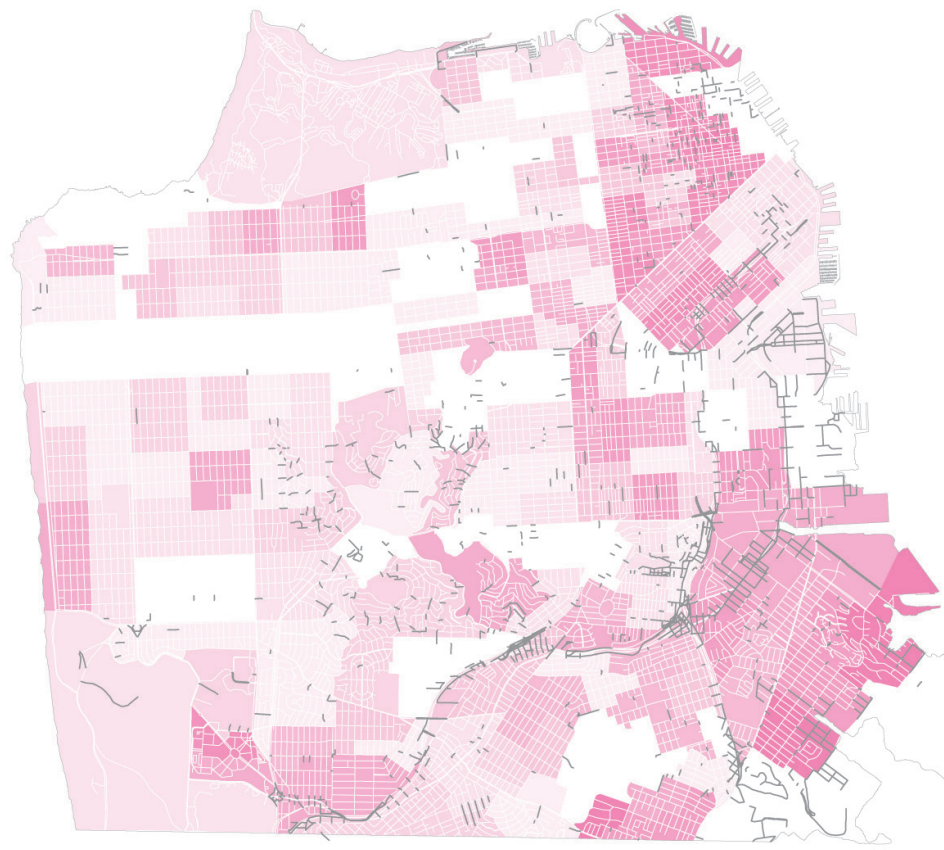

HOUSEHOLDS IN POVERTY

US Census, 2010

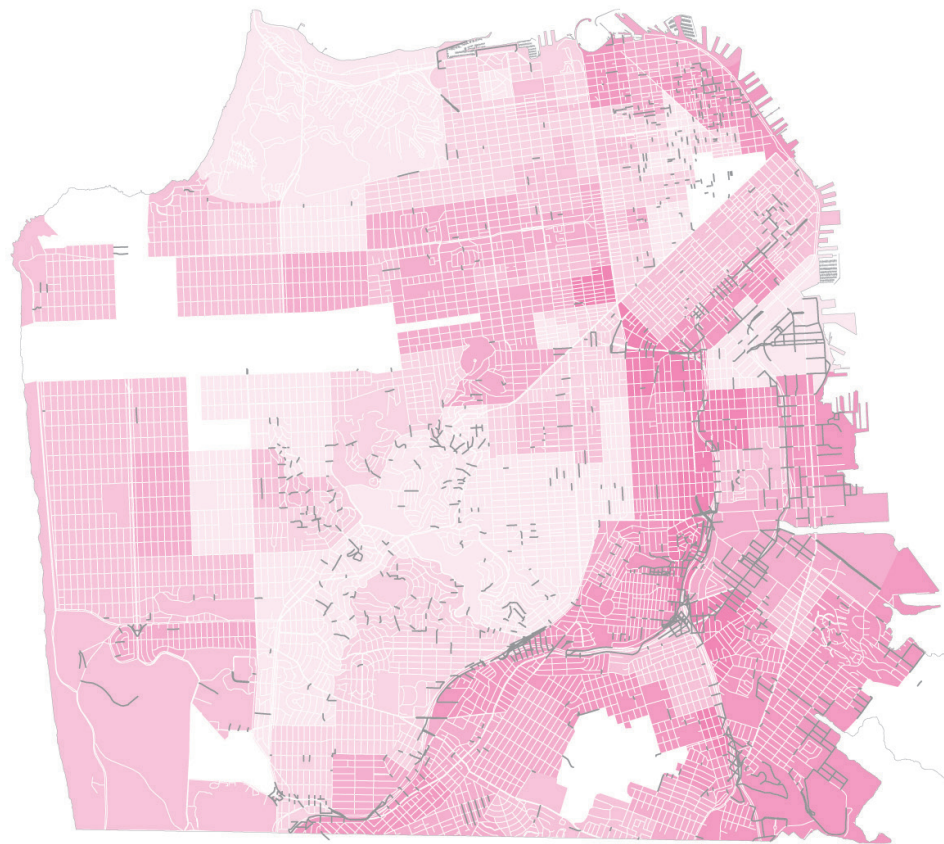

RESPIRATORY AILMENTS

US Census, 2010

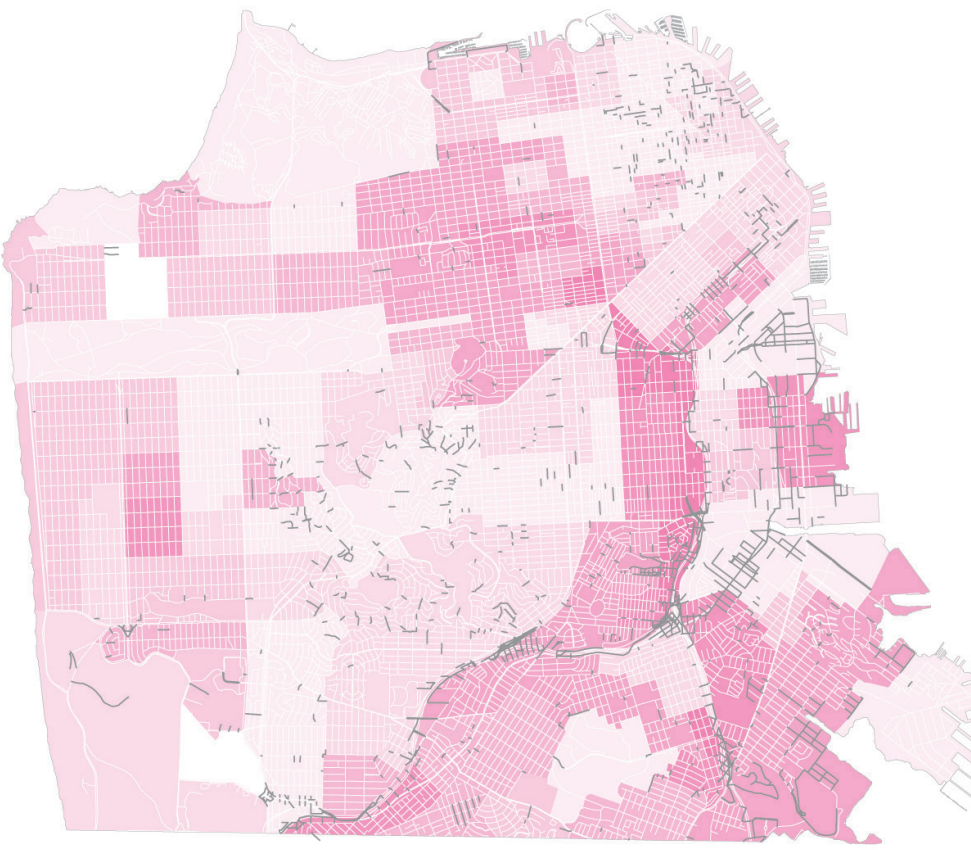

CANCER DIAGNOSIS

US Census, 2010

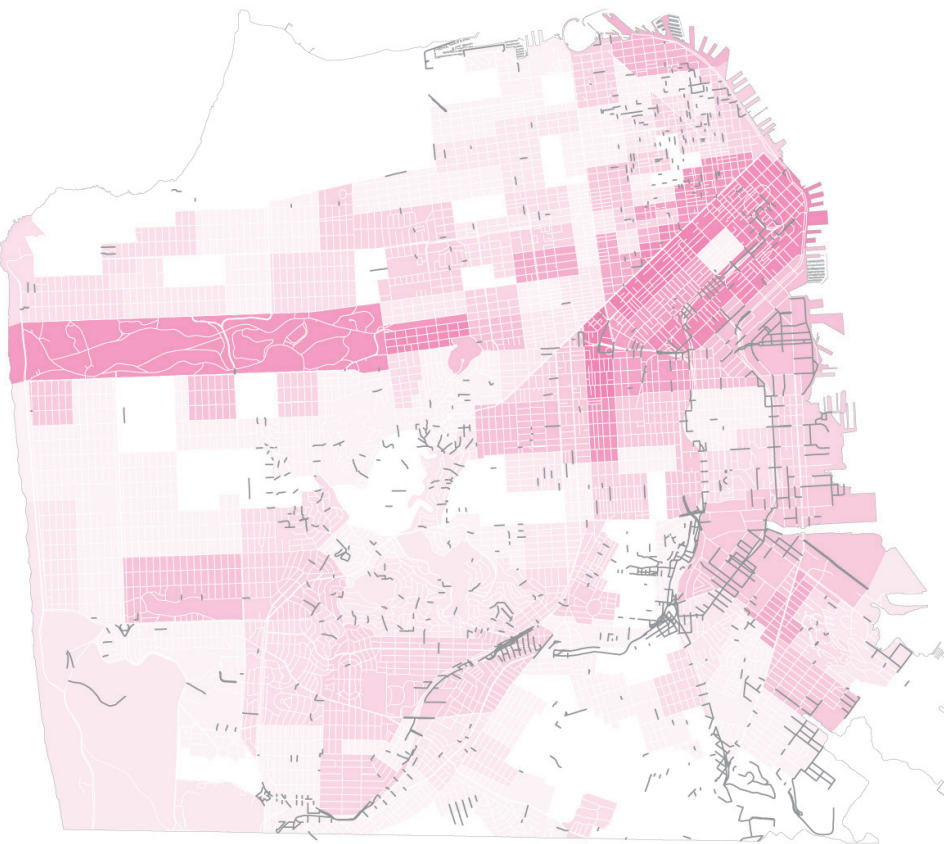

REPORTED CRIME

San Francisco Police Department, 2011 Data 


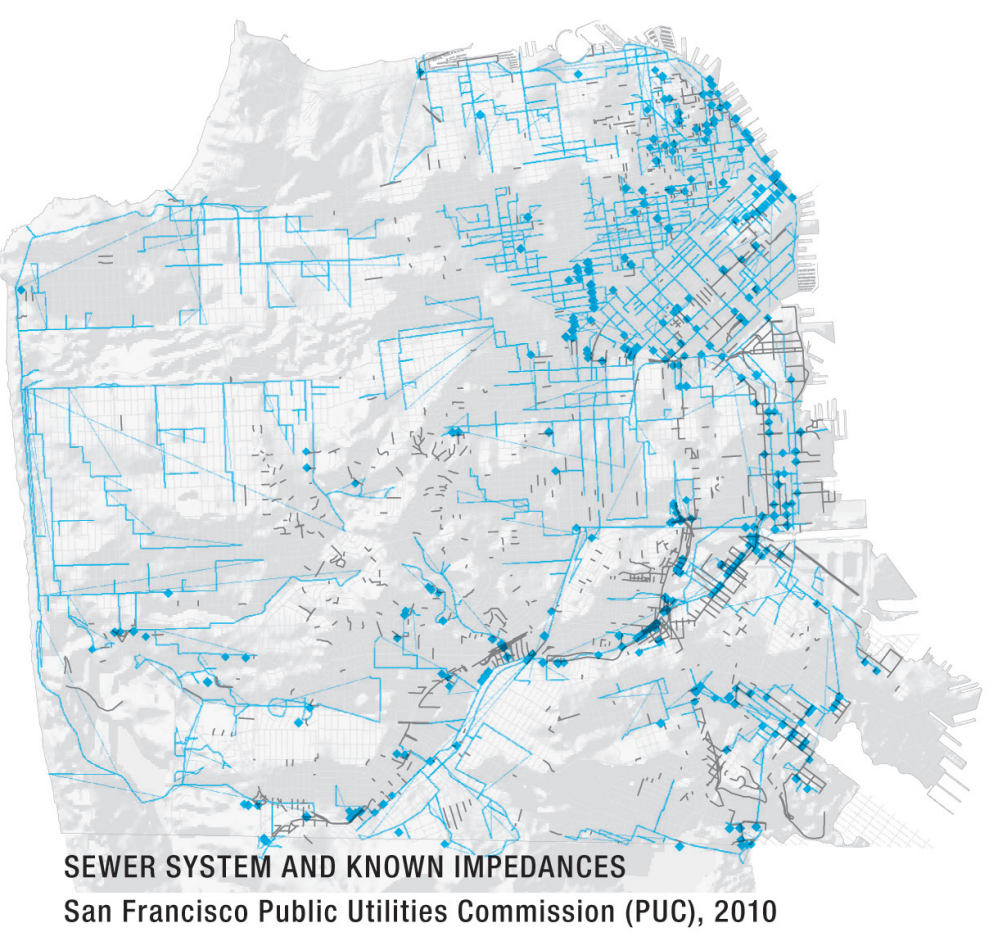

San Francisco Public Utilities Commission (PUC), 2010

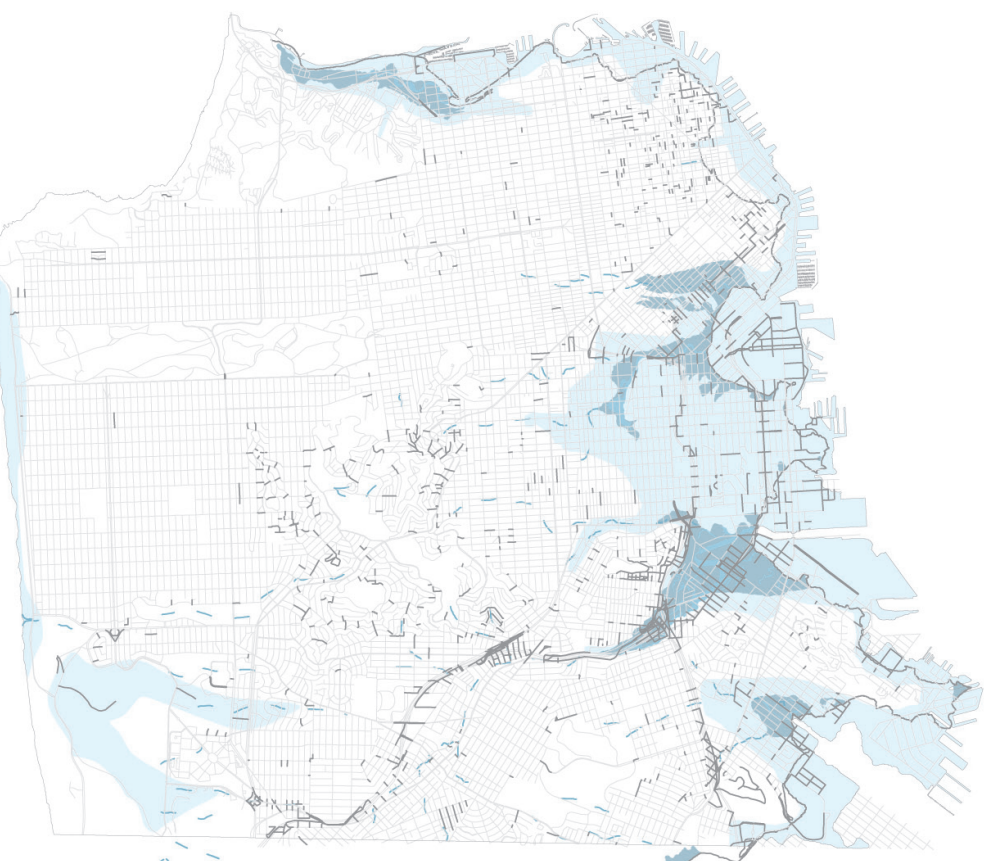

HISTORIC SHORELINE, CREEKS, SLOUGHS AND MARSHES

San Francisco Public Utilities Commission (w), 2010

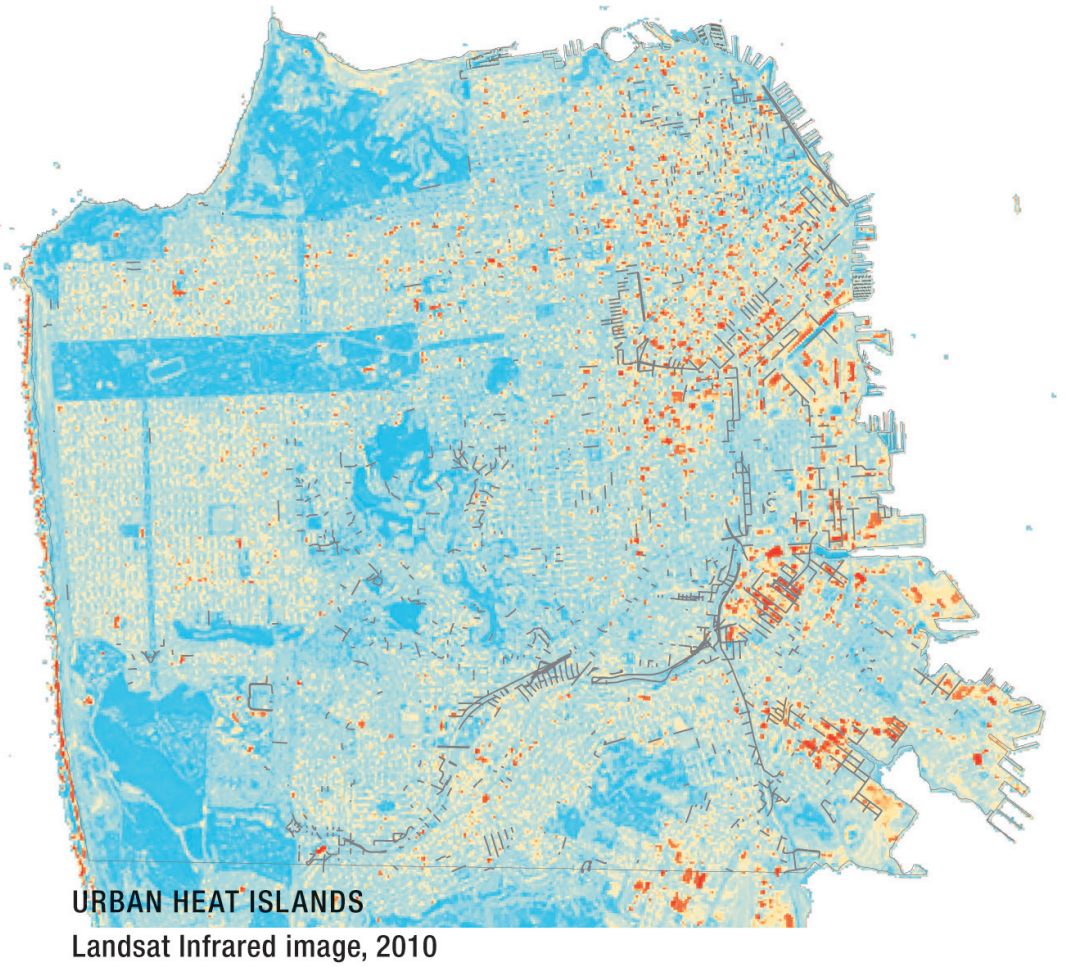

Landsat Infrared image, 2010

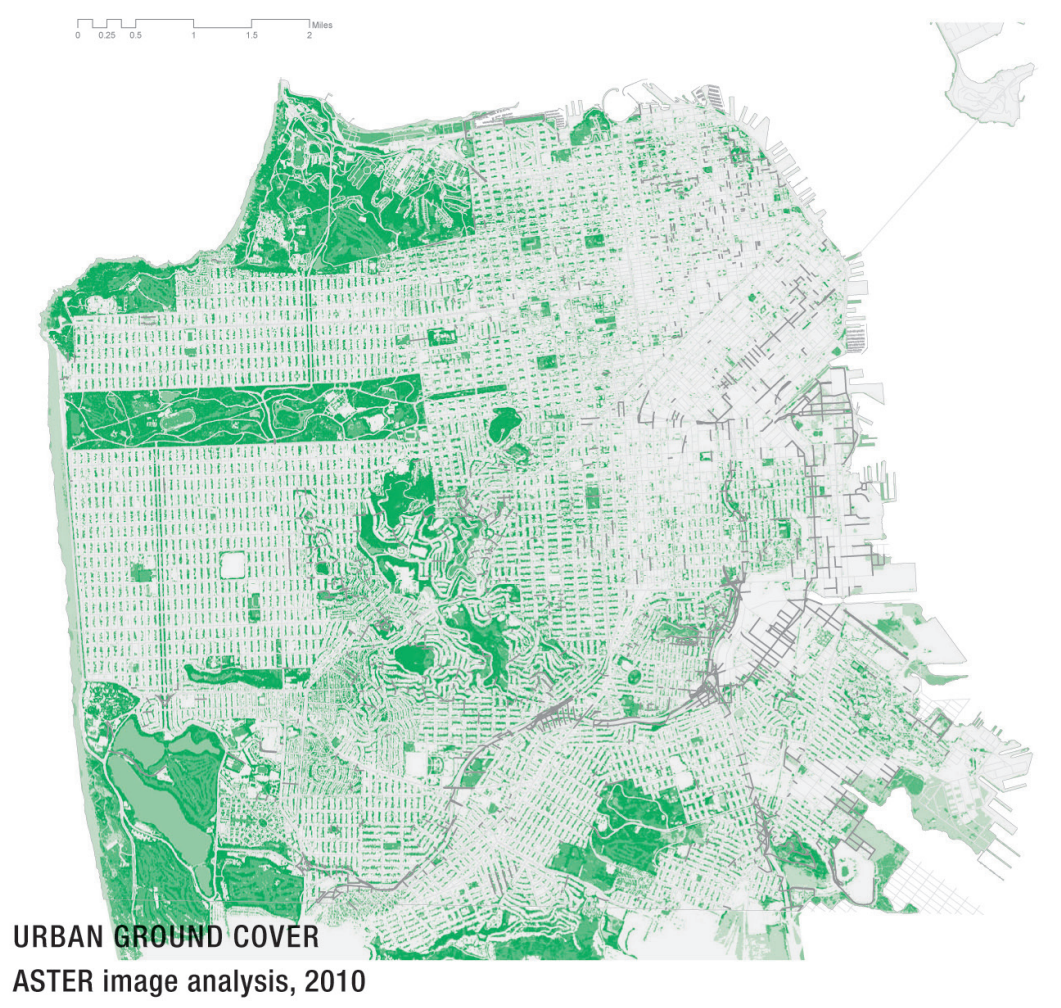


tend to buttress the enduring fallacy of the building as an independent object, versus merely an ephemeral part of many larger systems, cities chief amongst them. More recent studies on urban form, infrastructure, and even intellectual productivity have revealed uncanny parallels between biological systems and the ephemeral flexibility of urban form. In such a context the city is not even a formalist "collage," but rather, a contingent, emergent, and adaptive system whose complex dynamics will ever-evade measurement and certainty.

It is to this vision of the city that Local Code aspires. And we should remember that in such a dynamic and ephemeral nature, the code of DNA, or even our own Local Code, becomes much more like a real architectural blueprint than our profession's idealized version of it. In nature, as in the city, such elegant texts turn out to have only the most subtle effects on the way the world takes shape.

\section{Notes}

1. Matta-Clark, Gordon. Gordon Matta-Clark [IVAM Centre Julio González, Valencia 3 diciembre 1992/31 enero 1993: Musée Cantini, Marsella, 5 marzo/23 mayo 1993 : Serpentine Gallery, Londres 30 junio/15 agosto 1993]. [Valencia]: IVAM Centre Julio González, 1993. P. 183 See also Matta-Clark, G, J. Kastner, S. Najafi, F.Richard and J.A. Kroessler (2005), Odd Lots: Revisiting Gordon Matta-Clark's 'Fake Estates'. New York: Cabinet Books, Queens Museum of Art and White Columns.

2. See Chau, H-F. (2007). "Green Infrastructure for Los Angeles: Addressing Urban Runoff and Water Supply through Low Impact Development," City of Los Angeles Department of City Planning and UCLA Department of Urban Planning, McPherson, G. D. Nowak, Rowntree, R, (1994.) Chicago's Urban Forest Ecosystem:
Project. Washington, DC: U.S. Department of Agriculture. And Moll, G., (2002..). Urban Ecosystem Analysis for the Washington DC Metropolitan Area. http://www.americanforests. org/downloads/rea/AF_WashingtonDC2.pdf.

3. Miller, N. (1982) "Interview with Matta," in Matta: The First Decade, exhibition catalogue. Waltham, MA: Rose Art Museum, Brandeis University. P. 19.

4. Matta-Clark, G. undated and unaddressed proposal, c, 1974, Estate of Gordon MattaClark.

5, Bois, Yve-Alain and Rosalind Krauss "A User's Guide to Entropy," October, Vol. 78 (Autumn, 1996), pp. 38-88.

6. Jacob, MJ. Ed. (1985) Gordon Matta-Clark: A Retrospective, Chicago: Museum of Contemporary Art. P. 96.

7. For an extensive discussion of this genealogy, see Picon, Antoine, Digital Culture in Architecture. Basel, Birkhaüser, 2010

8. Bois, op cit.

9. My own discovery of which, ironically, postdates Local Code.

10. Matta-Clark, G. (1976) “Draft of A Resource Center and Environmental Youth Program for Louisada: A Proposal," dated 18 August 1976, Estate of Gordon Matta-Clark.

11. Piene, O. (1975) rejection of Matta-Clark's request to use the Center for Advanced Studies in the Visual Arts at MIT Letter dated December 8, 1975, Estate of Gordon Matta Clark.

12. Matta-Clark, G. (1975) letter to Wolfgang Becker, Neue Galerie, Aachen, June 10, 1975 Estate of Gordon Matta Clark

13. Jacobs, J. (1961). The Death and Life of Great American Cities. New York: Vintage. 428

14. Weaver, W. (1958) "A Quarter-Century in the Natural Sciences," Rockefeller Foundation. 1958. Annual report. New York: The Foundation. p. 1-91. The essay was mostly a reprint of one Weaver had written in 1947. Weaver, Warren "Science and Complexity" American Scientist, Vol. 36, No. 4 (October 1948), pp. 536-544.

15. See for example Hensel, M., A. Menges and M. Weinstock. (2004). "Fit Fabric: Versatility Through Redundancy and Differentiation," Emergence: Morphogenetic Design Strategies, $A D$, vol. 74, no. 3, Hensel, M. ed. (2006). "Techniques and Technologies in Morphogenetic Design" Architectural Design:A.D. 76, no. 2 or Chu, K. (2004) "Metaphysics of Genetic Architecture and Computation," Perspecta 35, 86.

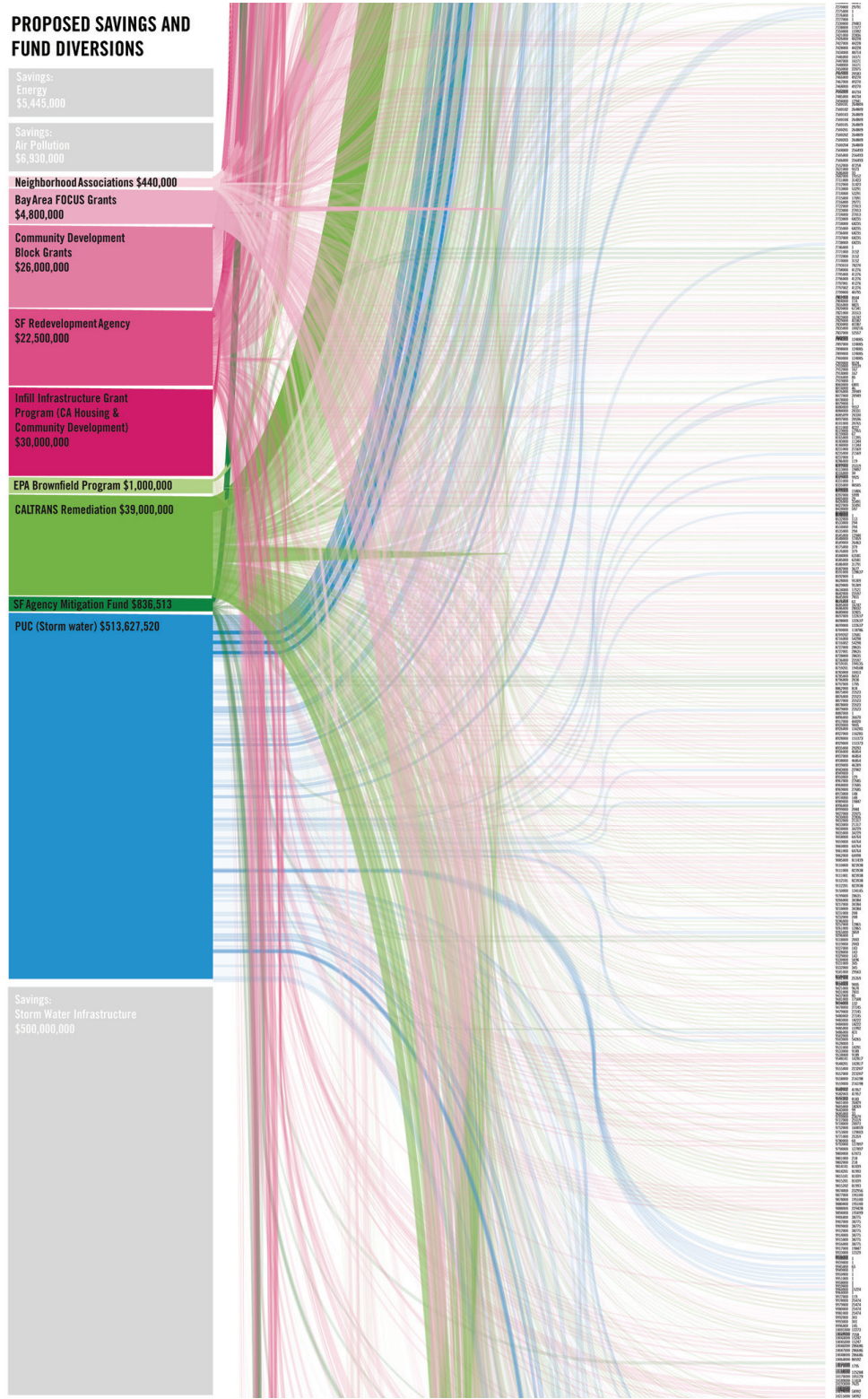

Funding diagram of Local Code Proposals, San Francisco, showing savings and targeted spending on each project site.

16. Jacobs. J. Op cit. For more on this biology, see amongst others J. Arjan, G. M. de Visser, et al (2003). "Perspective: Evolution and Detection of Genetic Robustness," Evolution International Journal of Organic Evolution, vol. 57, no. 9, also Piatigorsky, J. (2007) Gene Sharing and Evolution: The Diversity of Protein Functions. Cambridge, Mass: Harvard University Press., or Wagner, A. (2005) Robustness and Evolvability in Living Systems: Princeton Studies in Complexity. Princeton, NJ, Princeton University Press.
17. Forty Words and Buildings: A Vocabulary of Modern Architecture. New York, Thames and Hudson, 2004. 220.

18. See for example Bettencourt, L., J. Lobo, D. Helbing, C. Kühnert, and G. B. West, (2007). "Growth, innovation, and the pace of life in cities." Proceedings of the National Academy of Sciences, 104, 7301-7306. 


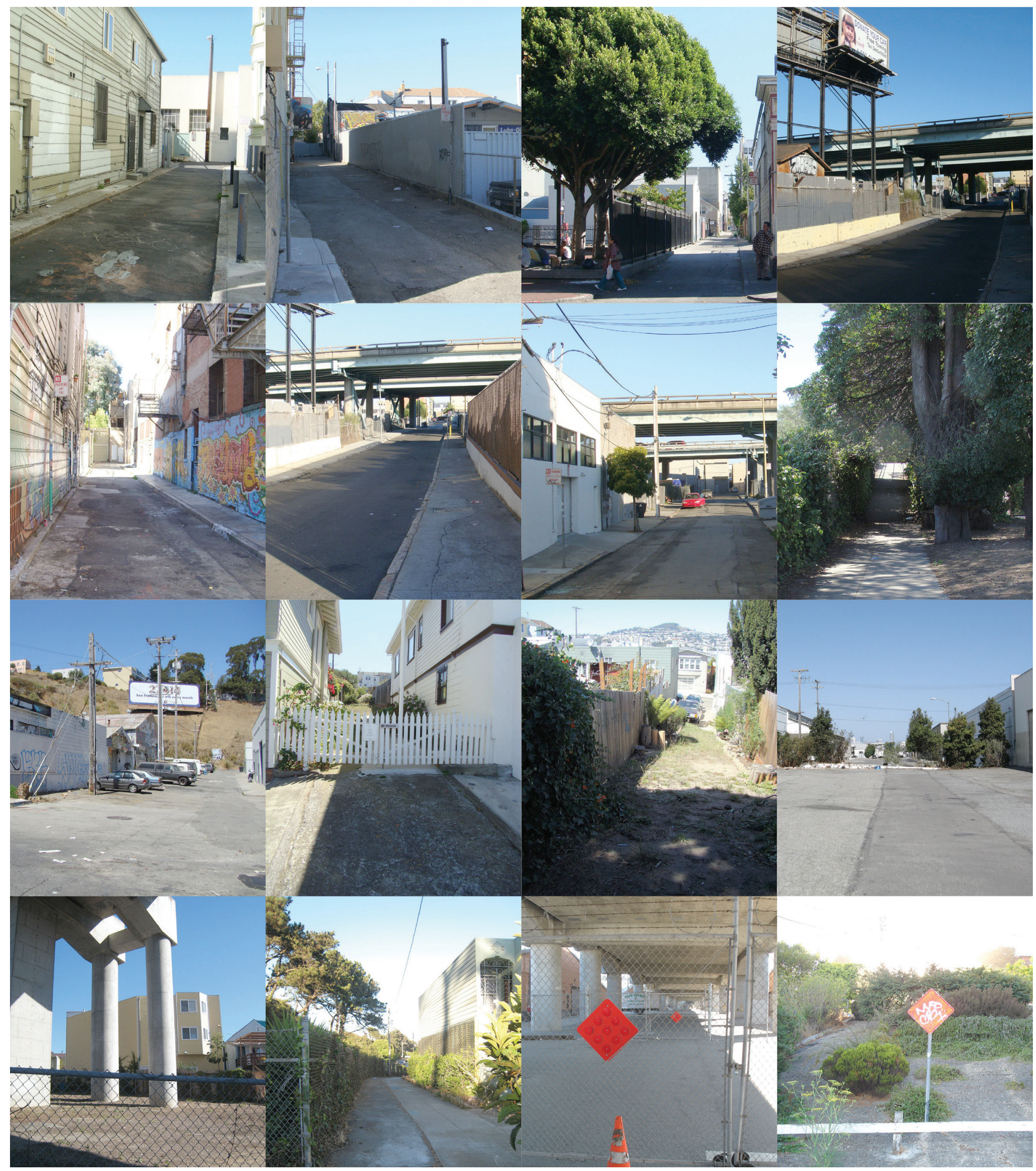

Site Survey of San Francisco. 